\title{
NITROUS OXIDE EMISSION FROM FARM DAIRY EFFLUENT APPLICATION IN GRAZED GRASSLAND
}

\author{
R. Bhandral ${ }^{1}$, N.S. Bolan ${ }^{1,2 *}$ and S. Saggar ${ }^{3}$ \\ ${ }^{1}$ Institute of Natural Resources, Massey University, Palmerston North, New Zealand; \\ ${ }^{2}$ Present Address: Centre for Environmental Risk Assessment and Remediation, CRC \\ Contaminant Assessment and Remediation of the Environment, University of South Australia, \\ Adelaide, Australia; ${ }^{3}$ Landcare Research, Private Bag 11052, Palmerston North, New Zealand. \\ *Corresponding author: Nanthi.Bolan@unisa.edu.au
}

\begin{abstract}
Intensification in dairying and increased production of farm dairy effluent (FDE) has raised concerns about gaseous nitrogen $(\mathrm{N})$ losses and their environmental implications. This study was undertaken to monitor changes in mineral-N and soil water-filled porespace (WFPS) in relation to $\mathrm{N}_{2} \mathrm{O}$ emission from application of FDE to dairy-grazed pasture. Pasture was irrigated with FDE in September 2003 (first irrigation) and January 2004 (second irrigation), preceded by grazing events. The $\mathrm{N}_{2} \mathrm{O}$ emission rate increased after application of FDE. Total amounts of $\mathrm{N}_{2} \mathrm{O}$ emitted from FDE application for first and second irrigation were $2 \%$ and $4.9 \%$, respectively, of the total $\mathrm{N}$ added through effluents. Difference in emission rates between the two irrigation events were attributed to difference in time lapse between the grazing event and FDE application. When FDE was applied immediately after grazing (second irrigation) higher emissions were observed.
\end{abstract}

Keywords: Denitrification; mineral-N; Carbon; Oxygen diffusion rate

\section{INTRODUCTION}

Intensification of dairy industry in New Zealand has led to increasing amounts of effluent being generated (Longhurst et al., 2000) which has resulted in growing concerns about environmental impacts of land application of this farm effluent (Luo et al., 2008a). One of the major concerns is loss of effluent nitrogen $(\mathrm{N})$ through nitrate leaching, ammonia volatilization and denitrification, thereby resulting in environmental degradation. The problem is further aggravated if effluent is applied on grazed pastures that are subject to compaction and excretal deposition (Luo et al., 2008b).

Nitrous oxide $\left(\mathrm{N}_{2} \mathrm{O}\right)$ is formed in soils during the microbiological processes of nitrification and denitrification, which are affected by a number of soil and climatic factors, such as soil enzyme activities, nitrate concentrations, $\mathrm{pH}$, available carbon, rainfall/irrigation, water-filled pore-space (WFPS) and temperature (Tiedje 1988, Bolan et al., 2004a, Luo et al., 2008c).

There have been very few comprehensive studies examining the emission of $\mathrm{N}_{2} \mathrm{O}$ from farm dairy effluent (FDE) application periodically to grazed paddocks as normally occurs on a commercial dairy farm. The combination of compaction caused by cattle treading during grazing and excretal deposition by grazing cattle is additional stimulants of 
$\mathrm{N}_{2} \mathrm{O}$ emission that will occur subsequent to effluent irrigation on a commercial farm. One of the main factors that influence emission in pasture is the grazing event (Oenema et al., 1997). Effluent irrigation immediately after the grazing event may enhance $\mathrm{N}_{2} \mathrm{O}$ emission from grazed pasture. This study was undertaken to examine the changes in mineral-N, dissolved organic carbon, oxygen diffusion rate (ODR) and WFPS in relation to $\mathrm{N}_{2} \mathrm{O}$ emission from application of FDE to dairy-grazed pasture.

\section{MATERIALS AND METHODS}

Nitrous oxide emissions and related soil and environmental parameters were monitored for two weeks following applications of FDE in September 2003 (spring $-1^{\text {st }}$ irrigation) and January 2004 (summer $-2^{\text {nd }}$ irrigation).

\section{Experimental site and soil characteristics}

The field site consisted of pasture grazed by dairy cows and was located on Massey University's $\mathrm{N}^{\circ} 4$ Dairy Farm in the Manawatu region of New Zealand (NZMS 260, T24, 312867). The site is located in a flat to easy rolling landscape ( $\sim 3 \%$ slope), which receives an average annual rainfall of $\sim 1000 \mathrm{~mm}$ supporting a mixed pasture of perennial ryegrass (Lolium perenne) and white clover (Trifolium repens).

The soil type was Tokomaru silt loam classified as Argillic-fragic Perch-gley Pallic soil in the Soil Classification (Hewitt, 1998). The soil at the experimental site had a total $\mathrm{N}$ of $0.35 \%$, organic matter of $6.2 \%$, bulk density of $1.01 \mathrm{Mg} \mathrm{m}^{-3}$ and cation exchange capacity of $22 \mathrm{cmol}_{+} \mathrm{kg}^{-1}$.
Two $40 \mathrm{~m} \times 40 \mathrm{~m}$ field sites were selected for the trial. The irrigated treatment site received two FDE applications and the control treatment did not receive any FDE. Both the sites have similar management practices and grazing events. The control plot which was about $200 \mathrm{~m}$ away from the irrigated plot was grazed at the same time and at same intensity as the irrigated plot. Two effluent irrigation events during $15^{\text {th }}$ to $28^{\text {th }}$ September $2003\left(1^{\text {st }}\right.$ irrigation $)$ and $28^{\text {th }}$ January to $11^{\text {th }}$ February, $2004\left(2^{\text {nd }}\right.$ irrigation) were monitored for $\mathrm{N}$ transformations in soils and $\mathrm{N}_{2} \mathrm{O}$ emission.

Effluent loading rate for each irrigation event was equal to the soil moisture deficit at the time of the effluent irrigation. The effluent was applied at hydraulic loadings of $25 \mathrm{~mm}$ and $21 \mathrm{~mm}$ the 1st and 2nd irrigation, respectively which resulted in $\mathrm{N}$ loading levels of 25.2 and $21.2 \mathrm{~kg} \mathrm{~N} \mathrm{ha}^{-1}$, respectively. Effluent was applied with a spitfire Mark I oscillating irrigator traveling at the rate of approximately $2.7 \mathrm{~mm} \mathrm{~min}^{-1}$.

The characteristics of the effluent applied are presented in Table 1. The paddock was grazed 8 days before the 1 st irrigation by 18 dairy cattle (112 cattle per hectare) for 12 hours and 1 day before the $2^{\text {nd }}$ irrigation by 22 cattle (135 per hectare) for 12 hours. The grazing took place at time and intensity that was normally followed under the management practices for the farm. The whole project was part of the deferred irrigation practice followed at the farm (Houlbrooke et al., 2004).

\section{Nitrous oxide measurement}

The $\mathrm{N}_{2} \mathrm{O}$ emissions for the above mentioned periods for the two experiments were measured using the closed chamber technique (Saggar et al., 2002, 2004a). 
Table 1. Characteristics of the farm dairy effluent applied during two applications on the Tokomaru silt loam soil.

\begin{tabular}{lcc}
\hline Properties & Irrigation 1 & Irrigation 2 \\
\hline Total suspended solids $\left(\mathrm{mg} \mathrm{L}^{-1}\right)$ & 245.2 & 268.6 \\
$\mathrm{pH}$ & 7.6 & 7.8 \\
Total N $\left(\mathrm{mg} \mathrm{L}^{-1}\right)$ & 95.6 & 101.4 \\
$\mathrm{NH}_{4}^{+}-\mathrm{N}\left(\mathrm{mg} \mathrm{L}^{-1}\right)$ & 68.2 & 75.4 \\
$\mathrm{NO}_{3}^{-}-\mathrm{N}\left(\mathrm{mg} \mathrm{L}^{-1}\right)$ & 0.6 & 0.4 \\
Total carbon $\left(\mathrm{mg} \mathrm{L}^{-1}\right)$ & 908.2 & 959.2 \\
Dissolved organic carbon $\left(\mathrm{mg} \mathrm{L}^{-1}\right)$ & 18.2 & 19.2 \\
$\mathrm{C}: \mathrm{N}$ ratio & 9.5 & 9.5 \\
Chemical oxygen demand $\left(\mathrm{mg} \mathrm{L}^{-1}\right)$ & 95 & 97 \\
Biochemical oxygen demand $\left(\mathrm{mg} \mathrm{L}^{-1}\right)$ & 105 & 112 \\
Total P $\left(\mathrm{mg} \mathrm{L}^{-1}\right)$ & 18.4 & 18.0 \\
\hline
\end{tabular}

Twenty chambers were installed per treatment in a zig zag pattern to cover the spatial variability in the field. During the monitoring of $\mathrm{N}_{2} \mathrm{O}$ flux immediately after a grazing event, installing chambers directly over the dung patch was avoided. The chambers, $25 \mathrm{~cm}$ in diameter, were inserted about $10 \mathrm{~cm}$ into the soil after the effluent application. Background $\mathrm{N}_{2} \mathrm{O}$ flux (grazed unirrigated control) was measured for the site one day before the effluent application. During the first week after the effluent application, measurements of the $\mathrm{N}_{2} \mathrm{O}$ emissions were made daily to capture major changes in $\mathrm{N}_{2} \mathrm{O}$ fluxes. This was followed by measurements on alternate days for rest of the experimental period till the fluxes decreased, approaching the background emission. The concentration of $\mathrm{N}_{2} \mathrm{O}$ in the gas samples taken at times $t_{0}, t_{30}$ and $t_{60}$ (30-min intervals) from each chamber was determined using a Shimadzu GC$17 \mathrm{~A}$ gas chromatograph equipped with a ${ }^{63} \mathrm{Ni}$-electron capture detector, and $\mathrm{N}_{2} \mathrm{O}$ emission rate was calculated from the change in concentration in the chamber over this time. Full descriptions of the calculation of $\mathrm{N}_{2} \mathrm{O}$ flux are presented elsewhere (Saggar et al., 2002, 2004a).

\section{Soil sampling}

On all days of $\mathrm{N}_{2} \mathrm{O}$ measurement, four soil samples were collected randomly from each site (irrigated and control) at 0 $5 \mathrm{~cm}$ depth to determine soil water content. Soil samples were also collected to measure DOC and mineral $\mathrm{N}$.

\section{Oxygen diffusion rate}

The oxygen diffusion rate (ODR) measurements were made to examine the difference in the diffusion rate between the irrigated and control treatments for all the two irrigations using ten replicate platinum electrodes (Glinski and Stepniewski, 1985). The electrodes were left overnight after installation at $5 \mathrm{~cm}$ soil depth to equilibrate with the soil solution. A voltage of $0.65 \mathrm{~V}$ was applied for $3 \mathrm{~min}$ and then the current between each electrode and a brass anode was read against an $\mathrm{Ag} / \mathrm{AgCl}$ reference electrode with a Jensen oxygen diffusion rate meter. 
The ODR was calculated using the following equation (Eq. 1):

ODR $\left(\mu \mathrm{g} \mathrm{O}_{2} \mathrm{~cm}^{-2} \mathrm{~min}^{-1}\right)=0.059 \times \mathrm{MC}(\mu \mathrm{A})[1]$

where, MC is the observed microelectrode current. The ODR was monitored on the first and the last day of the $\mathrm{N}_{2} \mathrm{O}$ measurement period for each of the two effluent irrigations.

\section{Dry matter yield}

To determine the pasture growth response to applied effluent, herbage was cut to a $2 \mathrm{~cm}$ height prior to effluent application for both the irrigations. Herbage accumulation after the effluent application was recorded at the end of the measurement period using $30 \mathrm{~cm} \times 30 \mathrm{~cm}$ cages, replicated 4 times.

The wet weight of herbage was recorded then oven dried at $70^{\circ} \mathrm{C}$ and dry matter (DM) recorded. The DM response to $\mathrm{N}$ input through effluent was calculated by the formula: $D M$ response $=\frac{D M \text { from effluent irrigated plot }-D M \text { from control plot }}{N \text { added through effluent }}$

\section{Effluent, soil and plant analyses}

The FDE was from the outlet of the aerobic pond of the dairy 4 farm of Massey University. Samples of effluent were analyzed for suspended solids, $\mathrm{pH}$, total $\mathrm{N}, \mathrm{NH}_{4}-\mathrm{N}, \mathrm{NO}_{3}-\mathrm{N}$, total carbon, dissolved organic carbon (DOC), chemical oxygen demand (COD), biological oxygen demand (BOD), total phosphorous and total potassium following the procedures published in standard methods (APHA, 1998).

Sub samples from each of the field moist soil samples were weighed $\left(\mathrm{M}_{\mathrm{t}}\right)$ and oven dried $\left(105^{\circ} \mathrm{C}\right)$ to a constant final mass $\left(\mathrm{M}_{\mathrm{s}}\right)$ and weighed again. The final oven dry mass and the difference between the field-moist and final masses $\left(M_{w}\right)$ were used to calculate the gravimetric soil water content $(\mathrm{SWC})=\left(\mathrm{M}_{\mathrm{w}} / \mathrm{M}_{\mathrm{s}}\right) \times 100$. The volumetric SWC was then calculated by multiplying the gravimetric SWC with the soil bulk density. Water-filled pore space (WFPS) was calculated as the ratio of the volumetric SWC to the total pore space (Saggar et al., 2004b).

The sieved $(<4 \mathrm{~mm})$ field-moist sub sample $(5 \mathrm{~g})$ was extracted with $0.5 \mathrm{M}$ $\mathrm{K}_{2} \mathrm{SO}_{4}$ solution, by shaking it for $1 \mathrm{hr}(1 \mathrm{~g}$ soil: $4 \mathrm{ml}$ extractant). The extracts were analysed for $\mathrm{NO}_{3}-\mathrm{N}$ and $\mathrm{NH}_{4}-\mathrm{N}$ by standard colorimetric methods (Keeney and Nelson, 1982) on an autoanalyser and for determining DOC by the dichromate oxidation (Tate et al., 1988) method using a spectrophotometer.

The plant samples were analysed for total $\mathrm{N}$ following the Kjeldahl digestion method (Mckenzie and Wallace, 1954).

\section{Statistical methods}

The means and standard error of means were calculated for WFPS, ODR, $\mathrm{N}_{2} \mathrm{O}$ fluxes, DM, soil mineral $\mathrm{N}$ concentrations and soil DOC values for both the effluent irrigations. The experiment was pseudoreplicated with respect to treatments only. Total emission data was subjected to an analysis of variance using arithmetic mean to determine the statistical significance of different effluent sources, using SAS for the Windows software package. Calculated indices were analysed using a test of least significant difference (LSD). Regression and correlation analysis between $\mathrm{N}_{2} \mathrm{O}$ emission and various soil properties was conducted using the SAS package.

\section{RESULTS}

\section{Properties of the effluent}

The chemical composition of FDE used for the two applications varied slightly (Table 1), and the total solid and total $\mathrm{N}$ 
contents were below the range reported in the literature (Wang et al., 2004). This may reflect the reduction in the concentrations resulting from storage and effluent treatment. However, about 70 $74 \%$ of $\mathrm{N}$ in $\mathrm{NH}_{4}{ }^{-} \mathrm{N}$ form measured in the FDE used in our studies is typical of the effluent $\mathrm{N}$ distribution values found in New Zealand (Longhurst et al., 2000).

\section{Nitrous oxide emisión}

Effluent applications at both events resulted in an increase the $\mathrm{N}_{2} \mathrm{O}$ emission over the unirrigated control. The emissions from FDE peaked within a few hours of application and subsequently dropped to reach the background level after 1-2 weeks of application (Figure 1).

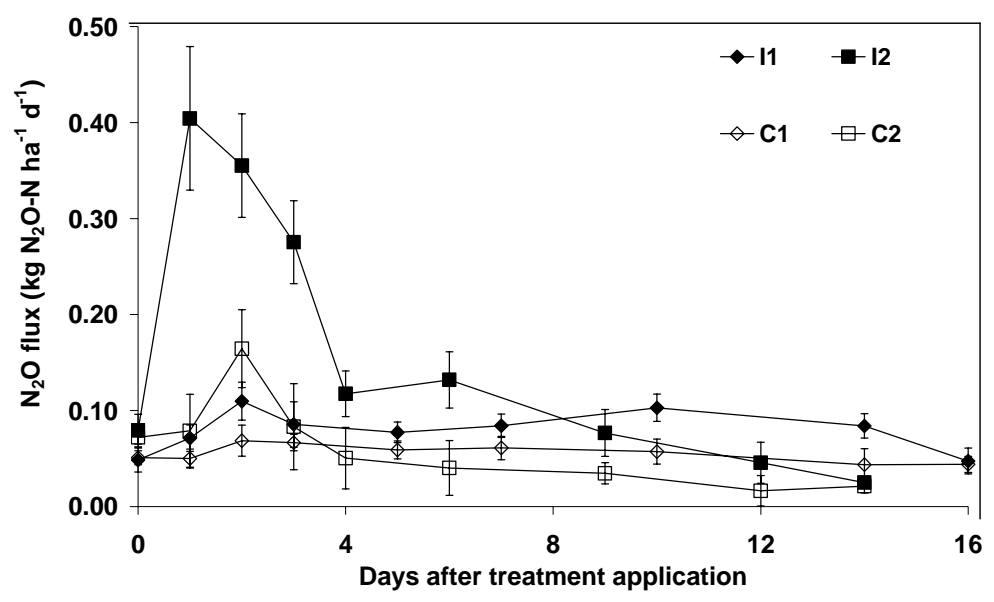

Figure 1. $\mathrm{N}_{2} \mathrm{O}$ fluxes $\left(\mathrm{kg} \mathrm{N} \mathrm{ha}^{-1} \mathrm{~d}^{-1}\right)$ during the two effluent application events. Each value represents a mean of twenty replicates with standard deviation shown by vertical bars. I1 and I2 represent the irrigated treatment and $\mathrm{C} 1$ and $\mathrm{C} 2$ represent the control treatment for the 1 st and $2^{\text {nd }}$ effluent application, respectively.

Peak emissions of 0.110 and $0.404 \mathrm{~kg} \mathrm{~N}$ $\mathrm{ha}^{-1} \mathrm{~d}^{-1}$ were attained within 4-24 hours of the effluent application for the $1^{\text {st }}$ and $2^{\text {nd }}$ irrigation, respectively.

A small second peak was observed only for the $1^{\text {st }}$ irrigation on day 10 . The emissions then declined to the base level within 16 and 14 days for the $1^{\text {st }}$ and $2^{\text {nd }}$ irrigations, respectively.

Nitrous oxide emission from the FDE treated pasture ranged from 0.047 to 0.110 and 0.025 to $0.404 \mathrm{~kg} \mathrm{~N}_{2} \mathrm{O}-\mathrm{N} \mathrm{ha}^{-1} \mathrm{~d}^{-}$ 1 for the $1^{\text {st }}$ and $2^{\text {nd }}$ irrigations, respectively. The results indicate that 44 and $78 \%$ of the total emission were emitted within a week for the $1^{\text {st }}$ and $2^{\text {nd }}$ irrigation, respectively.

The total amounts of $\mathrm{N}_{2} \mathrm{O}$ emitted from effluent application for the $1^{\text {st }}$ and $2^{\text {nd }}$ irrigation were $2.0 \%$ and $4.9 \%$, respectively, of the total $\mathrm{N}$ added through effluents (Table 2). Cumulative emissions from the irrigated site were 1.5 , and 2.8 times higher than that from the unirrigated control for respective irrigation events. The $\mathrm{N}_{2} \mathrm{O}$ flux from the control treatment remained almost stable with daily emission ranging from 0.0436 to 0.069 and 0.0164 to $0.164 \mathrm{~kg} \mathrm{~N}_{2} \mathrm{O}-\mathrm{N} \mathrm{ha}^{-1} \mathrm{~d}^{-1}$ for the $1^{\text {st }}$ and $2^{\text {nd }}$ irrigations, respectively. 
Table 2. Amount of $\mathrm{N}$ applied through farm dairy effluent irrigation and $\mathrm{N}_{2} \mathrm{O}$ emitted during the two fresh applications on the Tokomaru silt loam.

\begin{tabular}{lcccccc}
\hline Irrigation & Treatment & $\begin{array}{c}\text { Emission } \\
\text { period * }\end{array}$ & $\begin{array}{c}\mathbf{N} \text { added } \\
\left(\mathbf{k g ~ h a}^{-1}\right)\end{array}$ & $\begin{array}{c}\text { Peak } \\
\text { emission } \\
\text { rate }\end{array}$ & $\begin{array}{c}\mathbf{N}_{2} \mathbf{O}-\mathbf{N} \\
\mathbf{e m i t t e d} \\
\left(\mathbf{k g ~ h}^{-\mathbf{1}}\right)\end{array}$ & $\begin{array}{c}\text { Emission } \\
\text { factor } \\
(\mathbf{\%})\end{array}$ \\
\hline First & Irrigated & \multirow{2}{*}{17} & 23.9 & 0.110 & 1.357 & 2.0 \\
& Control & & Nil & 0.069 & 0.886 & - \\
\multirow{2}{*}{ Second } & Irrigated & \multirow{2}{*}{14} & 25.2 & 0.404 & 1.922 & 4.9 \\
& Control & & Nil & 0.164 & 0.679 & - \\
\hline
\end{tabular}

*Emission period $=$ Number of days for emission to reach the background level

$* *$ Emission factor $=\frac{\mathrm{N}_{2} \mathrm{O} \text { emitted }(\text { effluent treated plot })-\mathrm{N}_{2} \mathrm{O} \text { emitted }(\text { control plot })}{N \text { added througheffluent }} \times 100$

A slight increase in the emission was observed for the $2^{\text {nd }}$ irrigation, which coincided with the rainfall event (Fig. 1).

\section{Water filled pore space}

Soil WFPS for the irrigated and control treatment are shown in Figure 2. The calculated WFPS during the measurement period for both events was above the soil field capacity. Overall, WFPS was lower in the control treatments than the irrigated treatment. The WFPS values generally higher during the $2^{\text {nd }}$ than the $1^{\text {st }}$ irrigation. The range in WFPS values for the $1^{\text {st }}$ and $2^{\text {nd }}$ irrigation was 0.61 to 0.90 and 0.69 to 0.94 , respectively. The mean WFPS values for the entire measurement period for the irrigated treatment were 4.1 and $5.5 \%$ higher than the mean value of the control treatment for the respective irrigation events.

\section{Oxygen diffusion rate}

The ODR values declined immediately after the FDE application (Figure 3). Immediately after the $1^{\text {st }}$ and $2^{\text {nd }}$ irrigation
ODR values were 29.2 and $32.8 \%$ lower than the unirrigated control treatment. By the end of the measurement period of both the irrigation events ODR values increased to those observed in the control treatment. Overall, ODR values were slightly lower for the $2^{\text {nd }}$ than $1^{\text {st }}$ irrigation event, though the difference was not significant.

\section{$\mathbf{N}$ transformation in soil}

Application of FDE increased soil mineral $\mathrm{N}$ concentration (Figure $4 \mathrm{a}$ and $\mathrm{b}$ ). In general the trend in mineral-N distribution was same for both the irrigation events, with $\mathrm{NH}_{4}-\mathrm{N}$ concentration increasing immediately after FDE application and then decreasing progressively with time.

Nitrate concentration on the other hand showed an initial lag period before starting to increase. The highest $\mathrm{NH}_{4}-\mathrm{N}$ concentration of $22.7 \mathrm{mg} \mathrm{kg}^{-1}$ soil was reached within two days of the $1^{\text {st }}$ effluent application. The concentration then decreased to a minimum of $5.1 \mathrm{mg}$ $\mathrm{kg}^{-1}$ soil on the last day of the measurement period. 


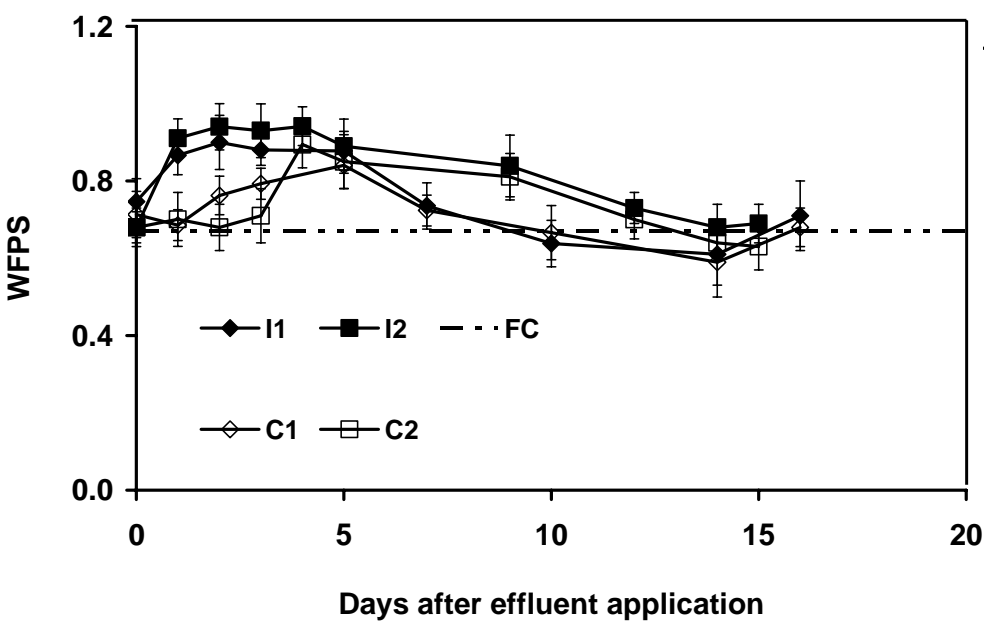

Figure 2. WFPS distributions for two freshly irrigated and corresponding control treatment (unirrigated). I1 and $\mathrm{I} 2$ represent the irrigated treatment and $\mathrm{C} 1$ and $\mathrm{C} 2$ represent the control treatment for the 1st and 2nd effluent application, respectively. Each value represents a mean of twenty replicates with standard deviation shown by vertical bars. FC=Field capacity.

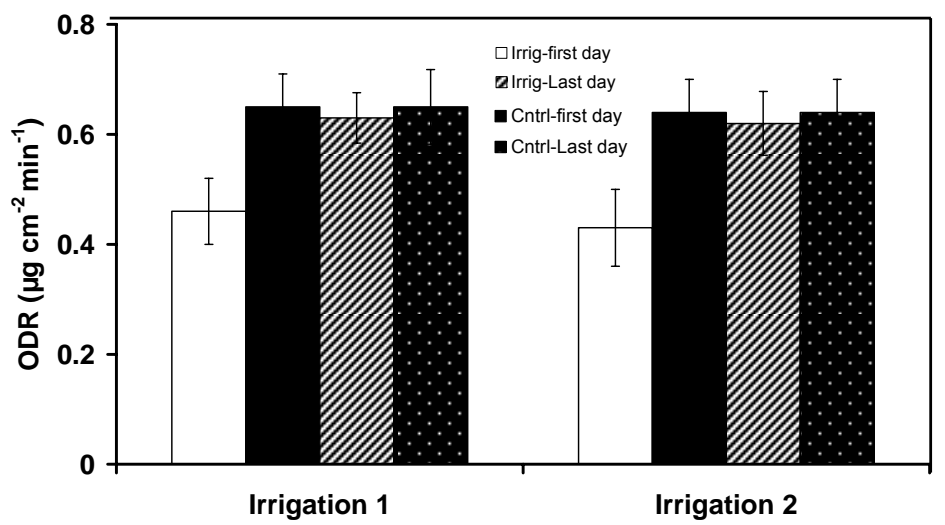

Figure 3. ODR $\left(\mu \mathrm{g} \mathrm{cm}^{-2} \mathrm{~min}^{-1}\right)$ for the experiments on the first and last day after treatment application for the two irrigation events. Each value represents a mean of four replicates with standard deviation shown by vertical bars. Irrig and Cntrl stand for irrigated and control.

The $\mathrm{NO}_{3}-\mathrm{N}$ concentration was found to peak to a concentration of $27.9 \mathrm{mg} \mathrm{kg}^{-1}$ soil on the third day after the $1^{\text {st }}$ effluent application. Decreases in both the $\mathrm{NH}_{4}-\mathrm{N}$ and $\mathrm{NO}_{3}-\mathrm{N}$ concentration were measured from the beginning to the end of the measurement period for the control treatment. The changes in the concentrations of the mineral $\mathrm{N}$ in the control treatment could be attributed to the excretal input from the grazing event a week before monitoring started. 

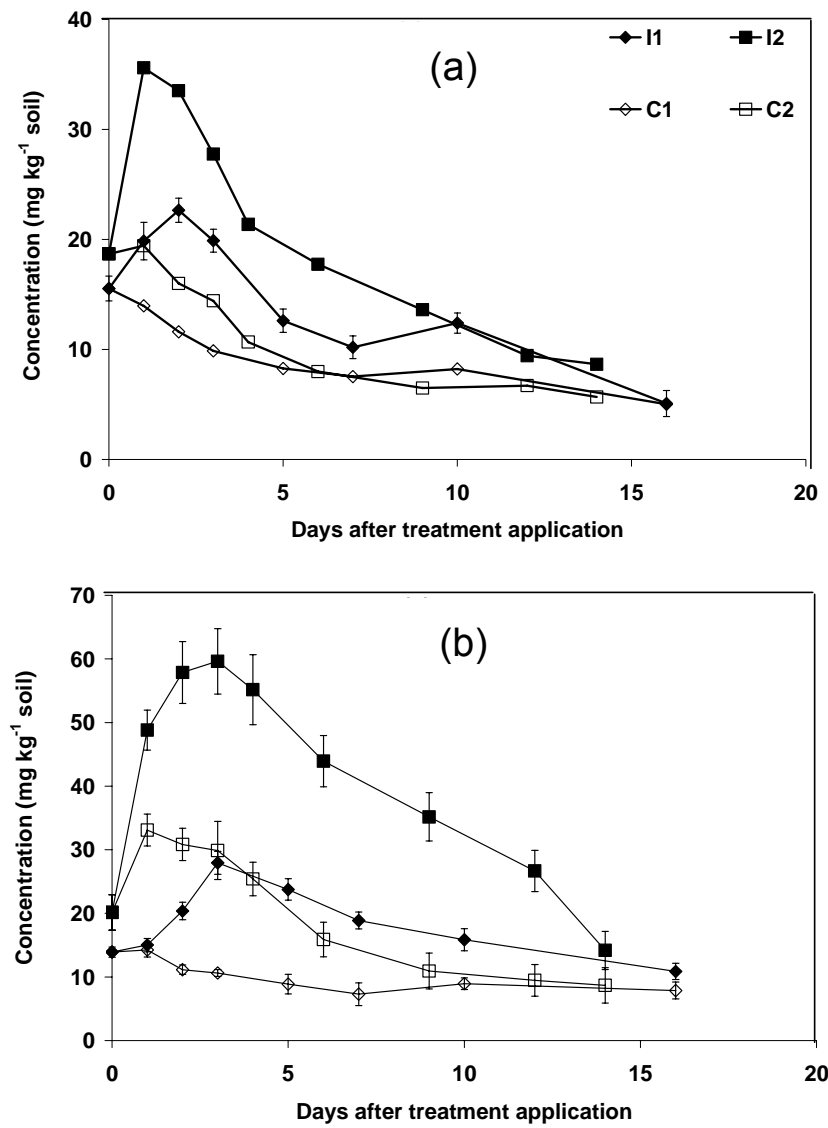

Figure 4. Distribution of (a) $\mathrm{NH}_{4}-\mathrm{N}$ concentration, and (b) $\mathrm{NO}_{3}-\mathrm{N}$ concentration during the $1^{\text {st }}$ and $2^{\text {nd }}$ effluent irrigation events. Each value represents a mean of four replicates with standard deviation shown by vertical bars. Please note the difference in the scale of $\mathrm{Y}$ axis. $\mathrm{I} 1$ and $\mathrm{I} 2$ represent the irrigated treatment and $\mathrm{C} 1$ and $\mathrm{C} 2$ represent the control treatment for the $1^{\text {st }}$ and $2^{\text {nd }}$ effluent application, respectively.

The pre-effluent irrigation mineral $\mathrm{N}$ concentration in the soil was higher for the $2^{\text {nd }}$ than $1^{\text {st }}$ event. A relatively large pool of both $\mathrm{NH}_{4}-\mathrm{N}$ and $\mathrm{NO}_{3}-\mathrm{N}$ existed in the soil, that was grazed a day before the application of the $2^{\text {nd }}$ irrigation. This could be attributed to the rapid transformation of the excretal (urine) $\mathrm{N}$ in the soil. The highest $\mathrm{NH}_{4}-\mathrm{N}$ concentration of $35.6 \mathrm{mg} \mathrm{kg}^{-1}$ soil was $133 \%$ of the $\mathrm{NH}_{4}-\mathrm{N}$ concentration added through the effluent, indicating some priming effect resulting from effluent application and from the excretal deposition. The $\mathrm{NO}_{3}-\mathrm{N}$ concentration also showed a similar trend with the levels being far higher than could be accounted for from all added $\mathrm{NH}_{4}-\mathrm{N}$ mineralised.

The range of the $\mathrm{NH}_{4}-\mathrm{N}$ concentration for the irrigated and the control treatment were 6.7 to $15.2 \mathrm{mg} \mathrm{kg}^{-1}$ soil and 5.3 to $7.7 \mathrm{mg} \mathrm{kg}^{-1}$ soil, respectively. During the 
entire measurement period, the soil $\mathrm{NO}_{3}-$ $\mathrm{N}$ concentration was higher in FDE irrigated site than the unirrigated control site (Figure $4 \mathrm{~b}$ ). The $\mathrm{NO}_{3}-\mathrm{N}$ ranged from 5.4 to $15.9 \mathrm{mg} \mathrm{kg}^{-1}$ soil and from 5.9 to $9.4 \mathrm{mg} \mathrm{kg}^{-1}$ soil for the irrigated and control treatments, respectively.

\section{Dissolved organic carbon}

Increases in the DOC concentration of the soil occurred with FDE application (Figure 5). This was as anticipated, because the FDE added soluble carbon to the soil. The increase in the DOC concentrations varied between the two irrigation events, but for both the events, an initial increase in DOC after the effluent application was followed by a decrease with time (Figure 5).
After the $1^{\text {st }}$ irrigation, DOC levels increased rapidly within two days to the peak level of $98.3 \mathrm{mg} \mathrm{kg}^{-1}$ soil, and then declined immediately, reaching $75.6 \mathrm{mg}$ $\mathrm{kg}^{-1}$ soil after 16 days of the FDE application. The DOC concentration in the soil under the control treatment fluctuated with time and the concentration varied by $18.7 \%$ between the first and the last day of the measurement period. The effect of effluent was observed throughout the measurement period with significant differences observed between the two treatments.

The DOC concentration measured during the $2^{\text {nd }}$ irrigation were higher than first irrigation event. The concentration on day 1 of this irrigation was $25.9 \mathrm{mg} \mathrm{kg}^{-1}$ and $43.2 \%$ higher than the $1^{\text {st }}$ irrigation.

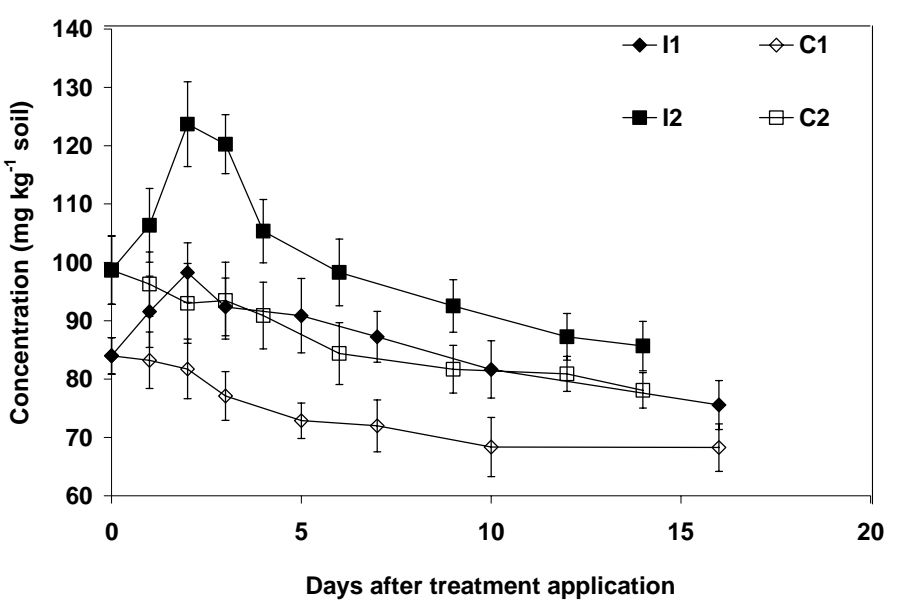

Figure 5. Distribution of soil DOC concentration $\left(\mathrm{mg} \mathrm{kg}^{-1}\right.$ soil $\left.\mathrm{d}^{-1}\right)$ during the monitoring period for the $1^{\text {st }}$ and $2^{\text {nd }}$ effluent application event. Each value represents a mean of four replicates with standard deviation shown by vertical bars. I1 and I2 represent the irrigated treatment and $\mathrm{C} 1$ and $\mathrm{C} 2$ represent the control treatment for the $1^{\text {st }}$ and $2^{\text {nd }}$ effluent application, respectively.

The concentrations during the entire measurement period ranged from 85.7 to $123.7 \mathrm{mg} \mathrm{kg}^{-1}$ soil for irrigated and 78.1 to $98.7 \mathrm{mg} \mathrm{kg}^{-1}$ soil for the control. The peak concentration for the irrigation treatment was 4.4 times higher than the total DOC added through effluent irrigation, indicating that FDE irrigation 
induced the mobilization of some of the excretal $\mathrm{C}$ input from the grazing a day before irrigation and native soil carbon. At the end of the two weeks $87.7 \mathrm{mg} \mathrm{kg}^{-1}$ soil of the DOC remained in the soil which was still significantly higher than that remaining in the control.

Over the entire measurement period the DOC values for the irrigation treatment ranged from 76.2 to $86.4 \mathrm{mg}$ $\mathrm{kg}^{-1}$ soil and for the control treatment from 71.9 to $78.3 \mathrm{mg} \mathrm{kg}^{-1}$ soil. The effect of FDE application on DOC concentration in the soil was observed only for a week.

\section{Dry matter yield}

The FDE irrigation increased the pasture DM yield (Table 3) and the yields in the FDE treatments were 2.0 and 2.2 times higher than those obtained for the respective unirrigated control. The yield response, expressed as $\mathrm{kg} \mathrm{DM} \mathrm{kg}^{-1} \mathrm{~N}$ was the higher for the $2^{\text {nd }}$ irrigation.

\section{DISCUSSION}

The addition of the FDE to dairy pastures, under normal farming conditions, resulted in significant increases in the $\mathrm{N}_{2} \mathrm{O}$ emissions for both irrigation events. A 1.5 and 2.8 fold increase in the emission was observed during the $1^{\text {st }}$ and $2^{\text {nd }}$ irrigation over the unirrigated treatment. The magnitude of increases in $\mathrm{N}_{2} \mathrm{O}$ emissions observed in our studies is in the same range as found with the application of animal wastes in Europe (Lowrance et al., 1998; Chadwick et al., 2000).

The FDE-induced increases in $\mathrm{N}_{2} \mathrm{O}$ have been attributed to the supply of soluble $\mathrm{C}, \mathrm{N}$ and water (Barton and Schipper, 2001). In our study, addition of water through FDE increased soil WFPS (Figure 2), resulting in anaerobic conditions and enhanced denitrification.
Denitrification typically is thought to proceed at optimal rates above 0.60 WFPS (Linn and Doran, 1984). Saggar et al. (2004a) showed that WFPS most strongly influences $\mathrm{N}_{2} \mathrm{O}$ fluxes in grazed pastures. They found generally high $\mathrm{N}_{2} \mathrm{O}$ emissions from grazed pasture sites when WFPS was above field-capacity (0.620.66). Over the entire measurement period, WFPS exceeded 0.60 for both effluent applications. This shows that most of the $\mathrm{N}_{2} \mathrm{O}$ emission might have been derived from the denitrification process rather than the nitrification process.

A significantly higher rate of denitrification at higher soil moisture levels has been observed in soils amended with liquid manure (Loro et al., 1997). However, in this study the WFPS in the two irrigation events was $>0.70$ in the unirrigated control and thus the addition of the water through FDE would have little effect on the $\mathrm{N}_{2} \mathrm{O}$ emission. Therefore, $\mathrm{N}$ and DOC from FDE would have a greater role in increasing emission.

As discussed earlier, the $\mathrm{N}_{2} \mathrm{O}$ emissions from effluent application to grazed pasture soils are highly dynamic. They vary with effluent quality and the period of effluent application (Sommer et al., 1996) and also with the time after application. For example, Clough and Kelliher (2005) observed no increase in $\mathrm{N}_{2} \mathrm{O}$ emission with the FDE application that supplied very low levels of $\mathrm{N}(1.5 \mathrm{~kg}$ $\mathrm{N} \mathrm{ha}^{-1}$ ).

Barton and Schipper (2001) found FDE application (50 $\mathrm{kg} \mathrm{N} \mathrm{ha}^{-1}$ ) increased $\mathrm{N}_{2} \mathrm{O}$ fluxes for only a short duration, with the flux returning to the background level within 3 to 48 hours. Studies by Watanabe et al. (1997), where the emissions were highest immediately after the application and then decreased with time are consistent with the post FDE application $\mathrm{N}_{2} \mathrm{O}$ emission rates reported in this study. 
Table 3. Total DM yield, and DM response to the added $\mathrm{N}$ for the experiments.

\begin{tabular}{lccccc}
\hline Irrigation & Treatment & $\begin{array}{c}\text { Monitoring } \\
\text { period } \\
(\mathbf{D a y s})\end{array}$ & $\begin{array}{c}\text { Total DM } \\
\left(\mathbf{k g ~ h a}^{-1}\right)\end{array}$ & $\begin{array}{c}\text { N added } \\
\left(\mathbf{k g ~ h a}^{-1}\right)\end{array}$ & $\begin{array}{c}\text { DM response } \\
\left(\mathbf{k g ~ D M ~ k g}^{-1} \mathbf{~ N}\right)\end{array}$ \\
\hline First & Irrigated & 14 & $204( \pm 45)$ & 23.9 & 4.4 \\
& Control & 14 & $102( \pm 35)$ & Nil & - \\
\multirow{2}{*}{ Second } & Irrigated & 15 & $251( \pm 56)$ & 25.2 & 5.5 \\
& Control & 15 & $113( \pm 51)$ & Nil & - \\
\hline
\end{tabular}

Our results indicate higher emissions from the $2^{\text {nd }}$ irrigation than from the $1^{\text {st }}$ Irrigation even though the FDE composition was more or less similar. This difference in the $\mathrm{N}_{2} \mathrm{O}$ emissions could be attributed to the difference in management and climatic factors preceding and during the effluent irrigation events. A grazing event immediately preceded the $2^{\text {nd }}$ irrigation.

The excretal deposition and the soil compaction caused by the grazing cattle could have led to increased emission. The concentration of the mineral $\mathrm{N}\left(\mathrm{NH}_{4}-\mathrm{N}\right.$ and $\mathrm{NO}_{3}-\mathrm{N}$ ) was higher in both the control and the irrigated treatments for the $2^{\text {nd }}$ irrigation than for the $1^{\text {st }}$ irrigation event. The combined effect of FDE and excretal substrates $(\mathrm{C}$ and $\mathrm{N})$ and their mobilization from the soil must have led to an increase in emission.

Build up of $\mathrm{NO}_{3}-\mathrm{N}$ was higher than could be accounted for by the nitrification of $\mathrm{NH}_{4}-\mathrm{N}$, indicating the excretal $\mathrm{N}$ added in the soil during the grazing must have undergone mineralization by the time the effluent was added. These results appeared to be consistent with the hypothesis (Sen and Chalk, 1993; Clough and Kelliher, 2005) that FDE and cattle urine application together cause a large scale priming effect in the soil $\mathrm{N}$ and $\mathrm{C}$, either by the solubilisation of the soil organic matter due to increased $\mathrm{pH}$ from the hydrolysis of the urine urea, or due to the $\mathrm{N}$ applied in the urine itself. Therefore, more $\mathrm{NO}_{3}{ }^{-}$was built-up in the FDE treatment in our studies. It remains unclear, however, why this effect was not observed in the $1^{\text {st }}$ irrigation where the site was grazed a week before the FDE application.

Farm effluent application commonly increases pasture yield (Bolan et al., 2004b; Wang et al., 2004). The increase in the dry matter yield with the application of the effluent can be attributed to the addition of both the water and the nutrients through effluent irrigation, and the level of response is influenced by the rate, method and time (season) of application, soil fertility, and climatic conditions (Ball and Field, 1982). For example, Goold (1980) recorded 43\% increase in the pasture yield when irrigated with FDE (irrigated at $12 \mathrm{~mm}$ depth, every 27 days) with a total of 156 $\mathrm{kg} \mathrm{N} \mathrm{ha}{ }^{-1}$ year $^{-1}$. Since our study did not include a control water treatment, it was not possible to isolate the effect of water from nutrients on the pasture DM yield response to effluent application.

Our results combined with another similar study (Saggar et al. 2005; Luo et al. 2008d) suggest that application of farm-dairy effluent during dry summer and autumn seasons can reduce $\mathrm{N}_{2} \mathrm{O}$ emissions. Our study also shows that delaying effluent application after grazing events could further reduce $\mathrm{N}_{2} \mathrm{O}$ emission 
by reducing the levels of surplus excretal mineral $\mathrm{N}$ and carbon $\mathrm{N}$ inputs.

\section{CONCLUSIONS}

Nitrous oxide emission from grazed dairy pasture was enhanced following application of FDE. Emission factor for the two irrigation events ranged from 2 to $4.9 \%$. Higher $\mathrm{N}_{2} \mathrm{O}$ emission was measured when FDE was applied immediately after a grazing event. The excretal deposition from grazing animals adds high amount of substrate in soil for $\mathrm{N}_{2} \mathrm{O}$ to be produced by the microorganisms. Application of effluent immediately after grazing event further creates conducive conditions for denitrification and also might cause priming effect in soil. Delaying effluentirrigation after a grazing event could reduce emissions by reducing levels of surplus mineral-N.

\section{REFERENCES}

APHA, 1998. Standard methods for the examination of water and wastewater. 20th edn. American public health association, Washington, DC.

Ball, B.C., Field, T.R.O. 1982. Response of nitrogen as affected by pasture characteristics, season and grazing management, in Lynch, P. B.: Nitrogen fertilisers in New Zealand agriculture. New Zealand Institute of Agricultural Science, Auckland, New Zealand, p. 29-44.

Barton, L., Schipper, L. A. 2001. Regulation of nitrous oxide emissions from soils irrigated with dairy farm effluent. J. Environ. Qual. 30, 18811887.

Bolan, N.S., Saggar, S., Luo, J., Bhandral, R., Singh, J. (2004a). Gaseous emissions of nitrogen from grazed pastures: processes, measurements and modelling, environmental implications, and mitigation. Adv. Agron. 84, 37-120.
Bolan, N.S., Horne, D.J., Currie, L.D. 2004b. Growth and chemical composition of legumebased pasture irrigated with dairy farm effluent. N.Z. J. Agric. Res. 47, 85-93.

Chadwick, D.R., Pain, B.F., Brookman, S.K. E. 2000. Nitrous oxide and methane emissions following application of animal manures to grassland. J. Environ. Qual. 29, 277-287.

Clough, T.J., Kelliher, F.M. 2005. Dairy farm effluent effects on urine patch nitrous oxide and carbon dioxide emissions. J. Environ. Qual. 34, 979-986.

Glinski, J., Stepniewski, W. 1985. Soil aeration and its rate for plants. CRC press, Boca Raton, Florida.

Goold, G.J. 1980. Rates of dairy shed effluent applied to pastures on clay soils in Northland. N.Z. J. Exp. Agric. 8, 93-99.

Hewitt, A.E. 1998. New Zealand soil classification. Landcare Research Science Series no. 1. Manawaki Whenua, Lincoln,Canterbury, New Zealand.

Houlbrooke, D. J., Horne, D. J., Hedley, M. J., Hanly, J. A., Scotter, D. R., Snow, V. O. 2004. Minimising surface water pollution resulting from farm-dairy effluent application to mole-pipe drained soils. I. An evaluation of the deferred irrigation system for sustainable land treatment in the Manawatu. N.Z. J. Agric. Res. 47, 405-415.

Keeney, D. R., Nelson, D. W. 1982. Nitrogeninorganic forms. In Page, A. L.: Methods of Soil Analysis. Madison, WI, p. 643-698.

Linn, D. M., Doran, J. W. 1984. Effect of water filled pore space on carbon dioxide and nitrous oxide production in tilled and nontilled soils. Soil Sci. Soc. Am. J. 48, 1267-1272.

Longhurst, R. D., Roberts, A.H.C., O'Connor, M. B. 2000. Farm dairy effluent: A review of published data on chemical and physical characteristics in New Zealand. N.Z. J. Agric. Res. 43, 7-14.

Loro, P. J., Bergstrom, D. W., Beauchamp, E. G. 1997. Intensity and duration of denitrification following application of manure and fertilizer to soil. J. Environ. Qual. 26, 706-713.

Lowrance, R., Johnson, J. C., Newton, G.L., Williams, R.G. 1998. Denitrification from soils of a year-round forage production system fertilized with liquid dairy manure. J. Environ. Qual. 27, 1504-1511. 
Luo, J., Ledgard, S.F., de Klein, C.A.M., Lindsey, S.B., Kear, M. 2008a. Effects of dairy farming intensification on nitrous oxide emissions. Plant Soil 309, 227-237.

Luo, J. Lindsey, S. B. Ledgard, S. F. 2008b. Nitrous oxide emissions from animal urine application on a New Zealand pasture. Biol. Fert. Soils 44, 463-470.

Luo, J., Saggar, S., Bhandral, R., Bolan, N., Ledgard, S., Lindsey, S., Sun, W. 2008c. Effects of irrigating dairy-grazed grasslands with farm dairy effluent on nitrous oxide emissions. Plant Soil 309, 119-130.

Luo, J., Ledgard, S. F., Lindsey, S. B. 2008d. A test of a winter farm management option for mitigating nitrous oxide emissions from a dairy farm. Soil Use Management 24, 121-130.

Mckenzie, H.A., Wallace, H.S. (1954). The kjelhahl determination of nitrogen. A critical study of digestion conditions-temperature, catalyst, and oxidising agent. Aust. J. Chem. 7, 55-70.

Oenema, O., Velthof, G.L., Yamulki, S., Jarvis, S.C. (1997). Nitrous oxide emissions from grazed grassland. Soil Use Management 13, 288-295.

Saggar, S., Andrew, R.M., Tate, K.R., Rodda, N.J., Hedley, C.B., Townsend, J.A. 2002. Measurements and modelling of nitrous oxide emissions from dairy pastures, in Currie, L. D., Loganathan, P.: Proceedings of the workshop on Dairy Farm Soil Management. Massey University: Palmerston North, New Zealand, p. 201-214.

Saggar, S., Andrew, R. M., Tate, K. R. Hedley, C. B., Rodda, N. J., Townsend, J. A. 2004a. Modelling nitrous oxide emissions from dairy-grazed pastures. Nutr. Cycling Agroecosyst. 68, 243-255.
Saggar, S., Bolan, N.S., Bhandral, R., Hedley, C.B., Luo, J. 2004b. A review of emissions of methane, ammonia, and nitrous oxide from animal excreta deposition and farm effluent application in grazed pastures. N.Z. J. Agric. Res. 47, 513-544.

Saggar, S., Bhandral, R., Bolan, N.S., Luo, J. 2005. Nitrous oxide emissions from land-applied effluents, in Zhu, Z., Minami, K., Xing, G.: $3^{\text {rd }}$ International Nitrogen Conference, Science Press USA Inc. p. 796-804.

Sen, S., Chalk, P.M. 1993. Chemical interactions between soil-N and alkalinehydrolyzing N-fertilizers. Fert. Res. 36, 239-248.

Sommer, S.G., Sherlock, R.R., Khan, R.Z. 1996. Nitrous oxide and methane emissions from pig slurry amended soils. Soil Biol. Biochem. 28, 1541-1544.

Tate, K.R., Ross, D.J., Feltham, C.W. 1988. A direct extraction method to estimate soil microbial-C - effects of experimental-variables and some different calibration procedures. Soil Biol. Biochem. 20, 329-335.

Tiedje, J.M. 1988. Ecology of denitrification and dissimilatory nitrate reduction to ammonium, in Zehnde, A. J. B.: Biology of anaerobic microorganisms. Wiley, New York, p 179-244.

Wang, H. L., Magesan, G.N., Bolan, N.S. 2004 An overview of the environmental effects of land application of farm effluents. N.Z. J. Agric. Res. $47,389-403$.

Watanabe, T., Osada, T., Yoh, M., Tsuruta, H. 1997. $\mathrm{N}_{2} \mathrm{O}$ and $\mathrm{NO}$ emissions from grassland soils after the application of cattle and swine excreta. Nutr. Cycling Agroecosyst. 49, 35-39. 